\title{
Didactic-technological paradigms in informatization of education
}

\author{
Irena Robert $^{1, *}$ \\ ${ }^{1}$ Institute of Education Management of the Russian Academy of Education, 105062, 5/16, 1B, \\ Makarenko str., Moscow, Russia
}

\begin{abstract}
The article substantiates and describes the factors affecting the formation of mass network communication in connection with scientific and technological achievements, calls and risks of the information society. It is based on and defines didactic-technological paradigms of the modern period of informatization of education and various techniques based on the implementation of described paradigms are proposed. The correlation of the paradigms and factors, which affect modern education development are also described.
\end{abstract}

\section{Introduction}

Analysis of the impact of the achievements of modern scientific and technological progress on the development of the informatization of education $[1,2,4,7,8,11]$ allowed to identify and formulate the main factors that have a significant impact on modern education in general, as well as modern formats and trends in the development of the informatization of education in connection with the challenges and risks of the information society of mass network communication and globalization:

- The access the user has to any information presented in various forms, in an unlimited volume;

- The access the user has to any partner or group of partners in network information interaction under conditions of freedom of choice;

- The opportunity to participate in any network groups (including social networks), the choice of which is subject only to personal opinion and desire of the user;

- "Distribution" and anonymity of users in the process of their network information interaction and, as a consequence, motivation for irresponsibility of the content component of information interaction;

- "Distribution" of the goal of network information interaction between users and, as a consequence, the process of interaction taking priority over its purpose;

- "Distribution" of attention of participants in the network information interaction and, as a consequence, the prevalence of visual components over the content;

- Concentration of user's attention on virtual objects and (or) processes and, as a consequence, distraction from real events, "loss" of communication with reality;

\footnotetext{
* Corresponding author: rena_robert@ mail.ru
} 
- The priority of technological and communicative solutions in the process of scientific research with weakening analytical-synthetic, inductive, deductive and experimental research methods and, as a consequence, the emergence of populism in science;

- Substitution of natural sciences by constructive (mathematics, computer science, engineering sciences) in the implementation of the possibilities of information and communication technologies (ICT), the creation of artificial objects whose level of complexity is comparable to natural ones.

\section{Methods}

In connection to this, let us go on to describe the factors that influence the development of the modern stage of informatization of education.

1. Globalization of information interaction and implementation of integral information activities by individuals who are geographically distributed and interacting in time, both in synchronous and asynchronous modes [4; 5].

2. Convergence of pedagogical technologies and information and communication technologies, the result of which is their mutual penetration, merging and, in a more rare manifestation, even their "splicing" $[1 ; 9 ; 10]$.

3. Distributed awareness of the individual reality (real images, processes, situations, plots) in the sense of virtual (existing under certain conditions) reality, as a rule, inadequate to the physical, social and mental characteristics of the individual and the realities of the world surrounding him [1].

4. Network information dependence of the individual on:

- Information interaction in conditions of psychologically relaxing "communication without problems" with anonymous partners (including in networks), both real and virtual;

- Use of information-intensive, visually attractive and meaningfully primitive information resource;

- Self-assertion in the process of virtual management of display objects or processes;

- Irresponsible and unpunished production of negative information, the creation of "fakes" (“jokes").

5. The individual's rejection of reality, due to the lack (or weakening) of the motivation for personal presence in the real world, including real communication with people, which entails a danger to the mental health of the person, including the formation of the so-called "mental infantilism syndrome".

The impact on modern education of the above factors, reflecting the scientific and technological achievements, challenges and risks of the information society of mass network communication and globalization, determines the need to identify and formulate appropriate paradigms of informatization of education, the implementation of which would, firstly, prevent or compensate for possible negative consequences of psychological pedagogical nature and, secondly, provide direction for the intellectual development of the learner, enable the individual to create radically new solutions to problematic situations, form individual custom views on the relationship and interdependence of objects and phenomena, create ideas based on systematization and generalization of information and knowledge.

Taking into account the above-mentioned positions, the Didactic-Technological Paradigm for the Informatization of Education (D-TPIE) will be understood as a set of scientific and pedagogical provisions and technological solutions oriented towards realizing the achievements of the modern information society of mass network communication and globalization, and preventing possible negative consequences of psychological and pedagogical nature, reflecting risks. 


\section{Research}

Let's enumerate the didactic-technological paradigms of the modern period of informatization of education, the realization of which, in part and spontaneously, is already being implemented in modern Russian education: 1) The paradigm of distributed education. 2) The paradigm of convergent education. 3) The paradigm of network open (or on-line) education (self-education). 4) The paradigm of high-tech education. Let us study in more detail the description of their substantive essence.

I. The distributed education paradigm develops ideas and their implementations in the field of e-learning (EE) and distance education technologies (DOT) in conditions of need for the masses to obtain higher education in the society that is imminent [3]; [4]. This paradigm is based on the idea of obtaining higher education by geographically distributed students. The implementation of the paradigm of distributed education is possible if there is appropriate and necessary material, technical, information, technological, administrative and educational support that determines the conditions for the functioning of the distributed higher education institution. The structure of the distributed higher educational institution reflects the idea of distributed education and is a modular structure that includes a basic module (Head Institution), modules - educational and methodological units (regional or municipal departments of the head university), having the status of subordination to the head university and modules - workplaces of students distributed at the place of their residence, receiving educational services from regional units. Information interaction between the units of the distributed higher education institution is carried out in strict accordance with its structure and status of the units. The information activity of the subjects of the educational process in a distributed higher educational institution is carried out using legitimate information and methodical support on the basis of high-tech software, hardware and information provided by the head university.

Positive features of the implementation of the paradigm of distributed education are:

- The social demand of the region's specialists who receive education at their place of residence, and those who remain in their region,

- The mass coverage of students in connection with training at their place of residence,

- Psychological and technological comfort of receiving educational content (for example, with "hypertext selection" of information),

- Development of the technological component of educational and methodological support of the educational process in connection with remote access to geographically distributed students,

- Improving the level of knowledge of information and communication technologies, both teaching and learning,

- Inclusion of students in professionally focused network communities via information interaction to solve problems arising in the learning process.

The negative features of the paradigm of distributed education include:

- A decrease in the level of training due to the lack of direct contact during communication, while monitoring the results of training activities in the conditions of the territorial removal of students and educators,

- Increase in financial costs for technical and technological support of the functioning of a distributed higher education institution,

- The disunity of students and educators, levelling the personal influence of the teacher on the student,

- The need to implement all training activities using ICT tools, the impact of which on the health of the user is unsafe, 
"Virtualization" of information interaction between students and, as a result, liquidation of the real student community, at best, the substitution of it for network student communities.

The paradigm of distributed education has been actively and quite recently realized in mega-universities (or distributed universities, universities) [4]. At the same time, it should be noted that the financial benefit of mass education prevails over the content, taking into account, among other things, the need to level the negative features of the distributed education paradigm.

II. The paradigm of convergent education is based on the realization of the idea of the convergence of pedagogical science and information and communication technologies [2; $9 ; 10]$. Given the vocabulary meaning of the word convergence (from English convergence - approximation, convergence, assimilation, or from the Latin convergens - coinciding or convergere to approach), we define convergence as coming together, likening or similarity, the coincidence of some characteristics or properties of objects independent of each other, processes, phenomena. At the same time, we define convergent education as an education characterized by the convergence of pedagogical science and information and communication technologies [9].

We will consider pedagogical science as the science of a specially organized purposeful and systematic activity of the educator, aimed at transferring knowledge, skills and social experience of their realization to the learner with the use of certain forms and methods of transferring the content of education. Modern information and communication technologies are considered in this context as a practical part of the scientific field of informatics, which is a combination of means, methods, methods of automated collection, processing, storage, transmission, use, production of information to obtain certain, obviously expected results. At the same time, information technology, the realization of which is carried out with the help of microprocessor, computer ("computer") equipment, has the following characteristic features:

- Realization of the capabilities of modern software, hardware and software, devices, transmission systems, broadcasting, production of information resources, information exchange;

- Use of special formalisms (logical and linguistic models) to represent declarative and procedural knowledge in electronic form (logical and linguistic modelling expands the possibilities of solving problems for non-formalizable areas of knowledge and spheres of human activity);

- Providing direct (without intermediaries) access to the dialog mode using professional programming languages and artificial intelligence tools;

- Ensuring the simplicity of the process of information interaction of the user with the computer, eliminating the need for regulatory support.

Given the above positions, the convergence of pedagogical science and information and communication technologies is seen as an approximation, convergence, likening of pedagogical technologies and ICT, as well as their mutual influence on each other, the emergence of similarities in the functions of pedagogical science and ICT, as well as in the structures of pedagogical technologies and ICT.

The process of convergence of pedagogical science and information and communication technologies initiates the development of the informatization of education through mutual influence of different areas of psycho-pedagogical science and information and communication technologies on each other. At the same time, the paradigm of convergent education is oriented towards the identification and implementation of the conditions for the mutual influence and penetration of information and communication technologies into pedagogical technologies and vice versa, and also on the identification of similarities in the functions and structures of information and communication technologies and pedagogical 
technologies for the formation of scientific and pedagogical practices for various educational subjects, the study of which is carried out using ICT tools [9].

III. The paradigm of network open (on-line) education (self-education) is based on the organization of information interaction between the subjects of the educational process in synchronous and (or) asynchronous modes and on providing remote access to information and teaching-methodological support [4]. The implementation of the paradigm of networked open education is also possible in the context of the organization of educational activities in social networks. At the same time, mutual assistance of the participants in the social network, with the "commune-like" organization of the network information interaction and the "age-like" organization of the creation of educational content is realized. The implementation of the paradigm of network open education is possible in the network communities of students, teachers or mentors, which are created at universities, at schools, both in a separate region and in larger territories. The principles of implementation of this paradigm are different: on the basis of principle, on the principle of solving certain professional problems, on the principle of exchange and examination of author's developments,

The implementation of the paradigm of network (open or on-line) education or selfeducation is based on:

- The implementation of popular MEP-platforms (or MOOK-platforms) that remotely provide the user with training materials for a particular subject or course or discipline submitted by higher education institutions (with the possibility of obtaining the relevant document);

- Informational interaction among the participants of the network community in the information and educational environment as a set of content and technological conditions for the implementation of information interaction between members of the network community and information activities with an interactive information resource that interacts with them as a subject of information interaction and personality [7, p. 157-185)];

- A "Wikipedia-like" organization for the development of an information resource or educational content and its provision is adequate to the principles of organization of the community, as well as its use in conditions of free access for each member of the community;

- Examination of jointly developed content in accordance with the pedagogical-ergonomic requirements for pedagogical products implemented on ICT bases [8, p. 253-280)].

IV. The paradigm of high-tech education is based on the implementation of the capabilities of automated complexes organized on the basis of high-tech devices that represent a system that must be able to recognize specific learning situations occurring in educational institutions of the educational institution and respond accordingly to them; while one of the systems can control the behaviour of the others according to algorithms worked out previously. An important feature of such an "intellectual building" of an educational institution is the unification of individual subsystems into a single managed complex, which differs from other ways of organizing an informational and educational space [8]. This is the most progressive concept of interaction between subjects of the educational process with educational equipment, including software, hardware and information complexes for educational purposes, when a user sets the desired situation in one team (setting up equipment, sending training materials, tracking the climate in the study room). Automatic and automated systems in accordance with external and internal conditions set and monitor the operating modes of all software, hardware and control systems. In this case, it is not necessary to use several control devices or elementary switches, for example, when operating computers, interactive whiteboard, peripheral equipment for laboratory work, for training in music classes, etc. including controlling lighting, and heating systems, video surveillance and alarm systems, gates and other 
equipment. In such an educational institution, it is enough to choose one of the scenarios for equipping the study room or the classroom system with a single click on the wall key (or remote control, touch pad, etc.). At the same time, the operation of all systems is self-tuned in accordance with the wishes of the administration or teacher, the time of day, weather, external illumination, etc., to ensure a comfortable atmosphere within the educational institution.

An important component that ensures the functioning of such an educational institution is the availability of high-tech equipment, robot-like information systems [2] and intelligent educational information systems $[11 ; 12]$.

To systematically generalize the above description of D-TPIE, we present in the form of a table (see Table 1) the correspondence between the proposed didactic-technological paradigms of informatization of education (the third column of the table) and the factors influencing the development of modern education, conditioned by the achievements, challenges and risks of the information society of mass network communication and globalization (the first column of the table), and the effects of these factors on the learner, both positive and negative (the second column of the table). The fourth column of the table presents possible options for practical implementation of D-TPIE in order to compensate for possible negative consequences of the influence of the modern society of mass network communication and globalization on the learner and on the development of education. In addition, the third column of the table presents proposals for implementing various options for sharing D-TPIE to obtain compensatory effects of their practical implementation.

It should be noted that in connection with the various conditions of the educational process in the educational institution (material, technical, information, educational, methodological, technological, administrative, etc.), the above paradigms are integrated (on technological grounds or "sectorally" by content); presented in the third column of the table.

For example, the "distribution" and anonymity of the user in the course of their network information interaction of educational purpose may entail their motivation for irresponsible attitude to the "exhibited" them in the network in the form of false or inaccurate text. This can be: borrowing (from the learner's side) text from other sources; including paragraphs in the text that are not relevant to the topic of work; an erroneous solution of a teaching problem, etc., which can provoke a negative attitude of a reviewer or an expert evaluating the student's work. To prevent these situations, it is proposed that the Paradigm of distributed education, the Paradigm of networked education (self-education) and the Paradigm of convergent education are implemented, for example, in the design of a distributed university $[3 ; 4 ; 5]$ and using scientific and pedagogical practices as a result of the phenomenon of the convergence of pedagogical science and ICT [10].

Table 1. Conformity of D-TPIE to the factors influencing the development of education, conditioned by the achievements, challenges and risks of the information society of mass network communication and globalization, and the consequences of these factors influence on the student.

\begin{tabular}{|c|l|l|l|}
\hline $\begin{array}{l}\text { Factors affecting the } \\
\text { development of } \\
\text { education, caused by } \\
\text { achievements, calls and } \\
\text { risks associated with } \\
\text { the information } \\
\text { community }\end{array}$ & $\begin{array}{l}\text { Consequences of the } \\
\text { influence of these factors } \\
\text { on the user (positive and } \\
\text { negative) }\end{array}$ & $\begin{array}{l}\text { D-TPIE suggested for } \\
\text { implementation }\end{array}$ & $\begin{array}{l}\text { Practical } \\
\text { implementation of } \\
\text { D-TPIE with the } \\
\text { purpose of } \\
\text { compensatory } \\
\text { influence }\end{array}$ \\
\hline 1 & $\mathbf{2}$ & $\mathbf{3}$ & $\mathbf{4}$ \\
\hline
\end{tabular}




\begin{tabular}{|c|c|c|c|}
\hline $\begin{array}{l}\text { 1. "Distribution" and } \\
\text { anonymity of the user } \\
\text { while partaking in } \\
\text { informational } \\
\text { communication }\end{array}$ & $\begin{array}{l}\text { Motivation of the user } \\
\text { for potential } \\
\text { irresponsible content } \\
\text { component of the } \\
\text { information interaction }\end{array}$ & $\begin{array}{l}\text { The paradigm of } \\
\text { distributed education } \\
\text { The paradigm of } \\
\text { network education } \\
\text { (self-education) } \\
\text { The paradigm of } \\
\text { convergent education }\end{array}$ & $\begin{array}{l}\text { Planning a } \\
\text { distributed } \\
\text { university }[3 ; 4 ; 5] \\
\text { Scientific- } \\
\text { Pedagogical } \\
\text { practices as a result } \\
\text { of the convergent } \\
\text { pedagogical } \\
\text { science } \\
\text { phenomenon and } \\
\text { ICT [10] }\end{array}$ \\
\hline $\begin{array}{l}\text { 2. The user's access to } \\
\text { the selection of any } \\
\text { information on the } \\
\text { Internet, in an } \\
\text { unlimited volume }\end{array}$ & $\begin{array}{l}\text { Absence of regulation in } \\
\text { the search, selection of } \\
\text { information, other than } \\
\text { the opinion or desire of } \\
\text { the user }\end{array}$ & $\begin{array}{l}\text { The paradigm of } \\
\text { networked open } \\
\text { education (self- } \\
\text { education); } \\
\text { The paradigm of high- } \\
\text { tech education }\end{array}$ & $\begin{array}{l}\text { Designing a } \\
\text { distributed } \\
\text { university [2;3;4] } \\
\text { The use of } \\
\text { intelligent methods } \\
\text { and models in } \\
\text { information } \\
\text { systems for } \\
\text { education [2; } \\
\text { eleven; } 12]\end{array}$ \\
\hline $\begin{array}{l}\text { 3. The availability of } \\
\text { the user to any partner } \\
\text { or to a group of } \\
\text { network information } \\
\text { partners }\end{array}$ & $\begin{array}{l}\text { The freedom of the user } \\
\text { to choose a partner in the } \\
\text { network information } \\
\text { interaction, the } \\
\text { possibility of his } \\
\text { involvement in any } \\
\text { network groups, the } \\
\text { choice of which is } \\
\text { determined only by his } \\
\text { personal opinion or } \\
\text { preferences }\end{array}$ & $\begin{array}{l}\text { The paradigm of } \\
\text { distributed education; } \\
\text { The paradigm of } \\
\text { networked education } \\
\text { (self-education) }\end{array}$ & $\begin{array}{l}\text { Designing a } \\
\text { distributed } \\
\text { university }[3 ; 4 ; 5]\end{array}$ \\
\hline $\begin{array}{l}\text { 4. "Distribution" of the } \\
\text { purpose of network } \\
\text { information interaction } \\
\text { between users }\end{array}$ & $\begin{array}{l}\text { The emergence in the } \\
\text { user of the priority of the } \\
\text { process of network } \\
\text { information interaction } \\
\text { over its purpose }\end{array}$ & $\begin{array}{l}\text { The paradigm of } \\
\text { distributed education; } \\
\text { The paradigm of } \\
\text { networked open } \\
\text { education (self- } \\
\text { education) }\end{array}$ & $\begin{array}{l}\text { Designing a } \\
\text { distributed } \\
\text { university }[3 ; 4 ; 5]\end{array}$ \\
\hline $\begin{array}{l}\text { 5. Concentration of } \\
\text { attention in the process } \\
\text { of implementation of } \\
\text { network information } \\
\text { interaction with } \\
\text { complete distraction of } \\
\text { user's attention from } \\
\text { real events }\end{array}$ & $\begin{array}{l}\text { The "loss" by the user of } \\
\text { temporary and (or) } \\
\text { spatial reference points } \\
\text { and, as a consequence, } \\
\text { the "loss" of } \\
\text { communication with the } \\
\text { actual reality }\end{array}$ & $\begin{array}{l}\text { The paradigm of } \\
\text { distributed education; } \\
\text { The paradigm of } \\
\text { network open education } \\
\text { (self-education); } \\
\text { Paradigm of convergent } \\
\text { education }\end{array}$ & $\begin{array}{l}\text { Designing a } \\
\text { distributed } \\
\text { university }[2 ; 3 ; 4] \\
\text { The use of } \\
\text { intelligent methods } \\
\text { and models in } \\
\text { information } \\
\text { systems for } \\
\text { education [2; } \\
\text { eleven; } 12]\end{array}$ \\
\hline
\end{tabular}




\begin{tabular}{|c|c|c|c|}
\hline $\begin{array}{l}\text { 6. "Distribution" of the } \\
\text { attention of participants } \\
\text { in the network } \\
\text { information interaction } \\
\text { in the context of using } \\
\text { any volume of } \\
\text { audiovisual information }\end{array}$ & $\begin{array}{l}\text { The emergence of a } \\
\text { destructive perception of } \\
\text { the content aspects of the } \\
\text { plot (plots) of the } \\
\text { network information } \\
\text { interaction }\end{array}$ & $\begin{array}{l}\text { The paradigm of } \\
\text { distributed education; } \\
\text { The paradigm of } \\
\text { network open education } \\
\text { (self-education); } \\
\text { Paradigm of convergent } \\
\text { education }\end{array}$ & $\begin{array}{l}\text { Designing a } \\
\text { distributed } \\
\text { university }[2 ; 3 ; 4] \\
\text { The use of } \\
\text { intelligent methods } \\
\text { and models in } \\
\text { information } \\
\text { systems for } \\
\text { education [2; } \\
\text { eleven; } 12]\end{array}$ \\
\hline $\begin{array}{l}\text { 7. Priority of } \\
\text { technological and } \\
\text { communicative } \\
\text { solutions in the process } \\
\text { of scientific research } \\
\text { and research }\end{array}$ & $\begin{array}{l}\text { Weakening of analytic- } \\
\text { synthetic, inductive, } \\
\text { deductive and } \\
\text { experimental methods in } \\
\text { the process of scientific } \\
\text { research }\end{array}$ & $\begin{array}{l}\text { The paradigm of } \\
\text { convergent education; } \\
\text { The paradigm of high- } \\
\text { tech education }\end{array}$ & $\begin{array}{l}\text { Scientific and } \\
\text { pedagogical } \\
\text { practices as a result } \\
\text { of the phenomenon } \\
\text { of the convergence } \\
\text { of pedagogical } \\
\text { science and ICT } \\
\text { [10] } \\
\text { The use of } \\
\text { intelligent methods } \\
\text { and models in } \\
\text { information } \\
\text { systems for } \\
\text { education [2;11; } \\
\text { 12] }\end{array}$ \\
\hline $\begin{array}{l}\text { 8. Substitution of } \\
\text { natural sciences with } \\
\text { constructive sciences } \\
\text { (mathematics, } \\
\text { computer science, } \\
\text { engineering sciences), } \\
\text { which actively realize } \\
\text { the possibilities of } \\
\text { information and } \\
\text { communication } \\
\text { technologies }\end{array}$ & $\begin{array}{l}\text { Creation of artificial } \\
\text { (virtual) objects, the } \\
\text { level of complexity of } \\
\text { which is comparable } \\
\text { with natural }\end{array}$ & $\begin{array}{l}\text { The paradigm of } \\
\text { convergent education; } \\
\text { The paradigm of high- } \\
\text { tech education }\end{array}$ & $\begin{array}{l}\text { Scientific and } \\
\text { pedagogical } \\
\text { practices as a result } \\
\text { of the phenomenon } \\
\text { of the convergence } \\
\text { of pedagogical } \\
\text { science and ICT } \\
\text { [10] } \\
\text { The use of } \\
\text { intelligent methods } \\
\text { and models in } \\
\text { information } \\
\text { systems for } \\
\text { education }[2 ; 11 ; \\
12]\end{array}$ \\
\hline $\begin{array}{l}\text { 9. Creation of } \\
\text { information products } \\
\text { by territorially } \\
\text { distributed collectives }\end{array}$ & $\begin{array}{l}\text { Realization of } \\
\text { opportunities of network } \\
\text { information interaction at } \\
\text { creation of information } \\
\text { products and occurrence } \\
\text { of "network information } \\
\text { reality" for developers }\end{array}$ & $\begin{array}{l}\text { The paradigm of } \\
\text { distributed education; } \\
\text { The paradigm of } \\
\text { networked open } \\
\text { education (self- } \\
\text { education); }\end{array}$ & $\begin{array}{l}\text { Designing a } \\
\text { distributed } \\
\text { university }[3 ; 4 ; 5]\end{array}$ \\
\hline
\end{tabular}

\section{Conclusion}

The implementation of the Didactic-technological paradigms of the modern period of informatization of the national education determines new formats and trends in the 
development of the informatization of education during the period of mass network communication of the information society, amongst which are the following:

- Modern trends in expanding the tracks of information interaction of educational purposes in information networks, both in terms of types of interaction, and in content.

- $\quad$ Ethics of conduct and legal restrictions in the process of information interaction in information networks, including the transfer of personal information.

- Substantial characteristics of the stability model of the guarding function of the information security of the learner's personality.

- Compensatory impact on the user, communicating with the "underground world" of the "dark Internet," where "informants of the informants" appear, distorting (inadvertently or with a certain intent) the content component of information interaction.

\section{References}

1. S. A. Beshenkov, M. I. Shutikova, E. V. Mindzaeva, Computer Science and Education, 8 (2015)

2. M. P. Karpenko, V. N. Fokin, A. V. Abramov, Innovations in Education, 9 (2012)

3. M. P. Karpenko, Information technology and systems in science, practice and education: V International Scientific Conference, November 27-29, 2012 (VSC RAS and RNO-A, Vladikavkaz, 2012)

4. O. Karpenko, Distributed mega-university in the modern educational system: monograph (Moscow, SGA, 2011)

5. O. Karpenko, I. A. Krutii, D. S. Zueva, SotsIs, 10 (2007)

6. M. V. Kovalchuk, Russian Nanotechnology, 6, 1-2 (2011)

7. I. Sh. Mukhametzyanov, Methodical recommendations for the prevention of negative medical consequences of the use of ICT in education (Moscow, IIO RAO, 2012)

8. I. V. Robert, Theory and methodology of informatization of education (psychological, pedagogical and technological aspects) (Moscow, BINOM: Laboratory of Knowledge, 2014)

9. I. V. Robert, Convergence of the sciences of education and information technologies as an evolutionary convergence of science and technology (for researchers and teachers of vocational education institutions) (Moscow, Concept and RAO UES, 2014)

10. I. V. Robert, Pedagogical Informatics, 3 (2015)

11. T. S. Shikhnabieva, I. M. Ramazanova, O. K. Ahmedov, Monitoring: Science and Technology, 2, 23 (2015)

12. T. Sh. Shikhnabieva, Automation of the learning process and knowledge control using intelligent models of educational content (2011) 